Tropical Journal of Pharmaceutical Research September 2021; 20 (9): 2005-2011

ISSN: $1596-5996$ (print); 1596-9827 (electronic) (C) Pharmacotherapy Group, Faculty of Pharmacy, University of Benin, Benin City, 300001 Nigeria.

\title{
Therapeutic effect of a combination of montelukast and vitamins $A$ and $D$ drops in children with bronchial asthma, and its influence on quality of life
}

\author{
Juan Zhang ${ }^{1 *}$, Junmin Zhang ${ }^{1}$, Fengxia Shi' ${ }^{1}$, Wei Tian ${ }^{2}$, Xiuzhen Liu $^{1}$ \\ ${ }^{1}$ Pediatric ward 1, ${ }^{2}$ Department of Neurosurgery, Han Dan Central Hospital, Handan, China \\ *For correspondence: Email: zhangjuan9069@163.com \\ Sent for review: 6 June 2021 \\ Revised accepted: 19 August 2021
}

\begin{abstract}
Purpose: To investigate the efficacy of a combination of montelukast and vitamins $A$ and $D$ drops in bronchial asthma children, and its effect on quality of life.

Methods: Sixty bronchial asthma children from June 2018 to June 2020 were collected and randomized into study group and control group (30 cases in each group). Control group received montelukast sodium (chewable tablets), while the study group received vitamins $A$ and $D$ drops (capsules) plus. Clinical efficacy, lung function, serum inflammatory factors, and quality of life were evaluated and compared.

Results: Compared with control group, total treatment effectiveness was higher and the symptom remission period was shorter in the study group $(p<0.05)$. Post-treatment, the parameters of FEV1 and FVC increased in both groups, but higher in the study group $(p<0.05)$. Serum levels of CRP and IL-4 in both groups decreased after treatment, while serum IL-10 levels were significantly up-regulated. Compared with control group, the levels of these indicators were improved in the study group $(p<0.05)$. Post-treatment Chinese Version of Pediatric Quality of Life Asthma Specific Scale (PedSQL) score was higher than before treatment, with higher values (for all indicators) in the study group $(p<0.05)$.

Conclusion: The combination therapy of montelukast and vitamins $A$ and $D$ drops produces good clinical efficacy in children with bronchial asthma. It significantly shortens the time taken for relief of clinical symptoms, improves lung function, reduces inflammatory response, controls asthma, and improves the quality of life of the patients.
\end{abstract}

Keywords: Bronchial asthma, Vitamin A and D, Monteloust, Clinical effects

\begin{abstract}
This is an Open Access article that uses a funding model which does not charge readers or their institutions for access and distributed under the terms of the Creative Commons Attribution License (http://creativecommons.org/licenses/by/4.0) and the Budapest Open Access Initiative (http://www.budapestopenaccessinitiative.org/read), which permit unrestricted use, distribution, and reproduction in any medium, provided the original work is properly credited.
\end{abstract}

Tropical Journal of Pharmaceutical Research is indexed by Science Citation Index (SciSearch), Scopus, International Pharmaceutical Abstract, Chemical Abstracts, Embase, Index Copernicus, EBSCO, African Index Medicus, JournalSeek, Journal Citation Reports/Science Edition, Directory of Open Access Journals (DOAJ), African Journal Online, Bioline International, Open-J-Gate and Pharmacy Abstracts

\section{INTRODUCTION}

Bronchial asthma, a type I allergic disease of the respiratory tract in pediatrics, is an inflammatory airway disease mediated by mast cells, eosinophils and lymphocytes [1]. Children with asthma repeatedly have chest tightness, cough, shortness of breath, wheezing and other symptoms, which seriously affect their growth and development, physical and mental health, and quality of daily life [2]. Thus, there is clinical need to strengthen asthma control, enhance lung function, and improve the quality of life of asthmatic children. 
The Guidelines for the Diagnosis and Prevention of Childhood Bronchial Asthma (2016 Edition) [3] suggests that inhalation corticosteroid (ICS) is a key therapy for bronchial asthma, while leukotriene receptor antagonist (LTRA) therapy improves clinical efficacy and prognosis of patients. However, long term use of large doses of glucocorticoids does not produce satisfactory control and protective effects in some children [4]. Currently, the incidence of asthma is increasing year by year in China. It not only affects the quality of life and growth of children, it also seriously affects their physical and mental health [5]. Therefore, it is necessary to evolve improved treatment strategies for childhood bronchial asthma. The present study was carried out to investigate the clinical effects of combination of montelukast and vitamins $A$ \& D drops on children with bronchial asthma.

\section{METHODS}

\section{General information}

Sixty (60) children with bronchial asthma were admitted to Han Dan Central Hospital., China from June 2018 to June 2020. They were randomly divided into study group and control group, using the random number table, with 30 cases per group. There were 18 boys and 12 girls aged between 6 and 10 years in the study group (mean age $=8.57 \pm 1.05$ years). Seventeen (17) patients had mild asthma, while 13 patients had moderate asthma. In the control group, there were 15 boys and 15 girls, aged 6.5 to 9.8 years (mean age $=8.69 \pm 0.95$ years), and they comprised 16 cases of mild asthma and 14 cases of moderate asthma. Table 1 shows that there were no statistically significant differences in general information between the two groups.

\section{Inclusion criteria}

(1) The study included subjects aged $\geq 6$, and diagnosis was conducted in line with Guidelines for the Diagnosis and Prevention of Bronchial Asthma in Children (2016 edition) [6]. The children suffered from mild or moderate asthma attacks. Children with mild attacks had mild symptoms, shortness of breath when walking, and supine posture. Moreover, they talked continuously, and they had mild irritability and anxiety, rapid breathing rate, slightly fast pulse, and some wheezing sound at the end of exhalation. The maximum peak expiratory flow (PEF) after short-acting $\beta 2$ agonist inhalation was more than $80 \%$ of the normal predicted value. Subjects with moderate attack presented shortness of breath, preference for sitting position, intermittent speech, emotional irritability or anxiety, three concave signs, obvious wheezing, accelerated breathing rate, and increased pulse rate. Their PEF reached 60 to $80 \%$ of the normal predicted value after SABA inhalation. (2) Subjects who had a children asthma control test (C-ACT) and had poor scores under 20, were included, as well as those whose family members signed informed consent form. Ethical approval was obtained for the human studies by the Ethics Committee of Han Dan Central Hospital (no. 2017-LC/34321. In addition, the study followed international guidelines for human studies owed [7].

\section{Exclusion criteria}

Children in the following categories were excluded from the study: (1) those who received glucocorticoid therapy within the previous one month; (2) children with a history of respiratory tract infection in the previous one month; (3) patients with hepatic and renal insufficiency; (4) those with severe primary heart and brain diseases; and (5) children who reacted adversely to the drugs used in this study.

\section{Treatments}

Children in both groups received conventional treatment, including cough-relieving and phlegmreducing drugs; oxygen inhalation, spasmolysis and asthma relief, and ICS budesonide aerosol treatment via inhalation of $100-200 \mu \mathrm{g}(1-2$ times), once or twice a day. Patients in both groups were given Montelukast Sodium Chewable Tablets at a dose of $4 \mathrm{mg}$ daily for 8 weeks. In addition, the patients in the study group received oral administration of vitamin $A$ and $\mathrm{D}$ drops (in capsules)

Table 1: General information on patients in the two groups

\begin{tabular}{lcccccc}
\hline \multirow{2}{*}{ Group } & \multicolumn{2}{c}{ Gender $(\mathbf{n})$} & \multicolumn{2}{c}{ Severity $(\mathbf{n})$} & \multirow{2}{*}{ Age } & \multirow{2}{*}{ Disease duration } \\
\cline { 2 - 5 } & Boys & Girls & Mild & Moderate & & \\
\hline Study & 18 & 12 & 17 & 13 & $8.57 \pm 1.05$ & $2.64 \pm 0.71$ \\
Control & 17 & 13 & 16 & 14 & $8.69 \pm 0.95$ & $2.58 \pm 0.68$ \\
$t$ & 0.069 & & 0.067 & -0.434 & 0.331 \\
$P$-value & 0.793 & & 0.795 & 0.666 & 0.742 \\
\hline
\end{tabular}


(Yikexin, Shandong Dayin Marine Biopharmaceutical Co. Ltd, SFDA, approval no. $=\mathrm{H} 37022974$; each capsule contained $3700 \mathrm{U}$ of vitamin D and $2000 \mathrm{U}$ of vitamin A) at a dose of 1 capsule per day.

\section{Clinical outcome indices}

(1) Clinical efficacy. The clinical efficacy was classified into markedly effective, effective, getting better, and ineffective.

(2) Remission time. The Remission time for cough and wheezing in both groups was recorded.

(3) Lung function. FEV1 and FVC in both groups before and after treatment (these were measured using ECO MEDICS infant lung function meter).

(4) Serum levels of CRP, IL-4 and IL-10 (3 ml of children's venous blood was drawn before and after treatment, and then the supernatant was centrifuged and stored in the refrigerator for use in determination of serum levels of CRP, IL-4 and IL-10 using enzyme-linked immunosorbent assay).

(5) Incidence of adverse reactions (dizziness, headache, nausea, vomiting, palpitation, etc.) in both groups during treatment.

(6) Quality of life. The PedSQL was used to assess the quality of life of children aged 5-12 years, including four aspects: symptom, anxiety, treatment and communication, with the total score calculated as average of scores of all the items answered: the higher the score, the higher the quality of life [8]

\section{Grading of treatment efficacy}

Treatment efficacy was categorized into four grades: (1) markedly effective, in which case, clinical symptoms such as cough and wheezing disappeared, and FEV1 increased by $35 \%$ or above; (2) effective, in which case, clinical symptoms were significantly reduced, and FEV1 increased by 25 to $35 \%$; (3) improved, which referred to patients in whom the clinical symptoms were reduced, and FEV1 went up by 15 to $25 \%$; and (4) ineffective, for patients who did not experience any reductions in clinical symptoms, and whose FEV1 increased by $<15$ $\%$. Total effectiveness (TE) was calculated as in Eq 1.

$\mathrm{TE}(\%)=\{(\mathrm{Ns}+\mathrm{Ne}) / \mathrm{Nt}\} 100$

where Ns = no. of significantly effective cases, $\mathrm{Ne}=$ no. of effective cases, and $\mathrm{Nt}=$ total no. of cases.

\section{Statistical analysis}

Statistical software SPSS 25.0 was adopted for data processing. Independent paired $t$-test was used for analysis of measurement data expressed as mean \pm standard error of the mean (SEM), while $x^{2}$ test was used for analysis of enumeration data expressed as numbers and percentages [n (\%)]. Values of $p<0.05$ indicated significant differences.

\section{RESULTS}

\section{Clinical efficacy}

Clinical effectiveness in the study group $(90.00 \%)$ was markedly higher than that in the control group $(63.33 \%)(p<0.05)$. These results are shown in Table 2.

\section{Time taken for remission of clinical symptoms}

As shown in Table 3, the time lag before remission of children's cough and wheezing was significantly shorter in the study group than in control group $(p<0.05)$.

\section{Pulmonary function indices}

There were significant post-treatment increases in FEV1 and FVC of both groups, when compared to pre-treatment values. However, FEV1 and FVC values were higher in study group after treatment than in control group $(p<$ 0.05), as shown in Table 4.

Table 2: Comparison of clinical efficacy between the two groups

\begin{tabular}{lccccc}
\hline Group & $\begin{array}{c}\text { Markedly } \\
\text { effective }\end{array}$ & Effective & $\begin{array}{c}\text { Getting } \\
\text { better }\end{array}$ & Ineffective & $\begin{array}{c}\text { Total } \\
\text { effectiveness }\end{array}$ \\
\hline Study & 14 & 13 & 2 & 1 & $27(90.00)$ \\
Control & 8 & 11 & 8 & 3 & $19(63.33)$ \\
$T$ & & & & & 5.963 \\
$P$-value & & & & & 0.015 \\
\hline
\end{tabular}


Table 3: Comparison of time taken for remission of clinical symptoms (day)

\begin{tabular}{lccc}
\hline Group & $\begin{array}{c}\text { Remission period for } \\
\text { cough }\end{array}$ & $\begin{array}{c}\text { Remission period for } \\
\text { wheezing }\end{array}$ & $\begin{array}{c}\text { Remission period for } \\
\text { lung wheezes }\end{array}$ \\
\hline Study & $5.36 \pm 1.12$ & $4.16 \pm 1.17$ & $2.90 \pm 1.06$ \\
Control & $7.26 \pm 1.14$ & $6.10 \pm 1.09$ & $5.63 \pm 0.88$ \\
$t$ & -6.478 & -6.591 & -10.806 \\
$P$-value & $<0.001$ & $<0.001$ & $<0.001$ \\
\hline
\end{tabular}

Table 4: Comparison of pulmonary function indices before and after treatment

\begin{tabular}{lcccc}
\hline \multirow{2}{*}{ Group } & \multicolumn{2}{c}{ FEV1/L } & FVC/L & \\
\cline { 2 - 5 } Study & Before treatment & After treatment & Before treatment & After treatment \\
\cline { 2 - 5 } Control & $1.24 \pm 0.19$ & $1.89 \pm 0.18^{*}$ & $0.79 \pm 0.18$ & $1.62 \pm 0.23^{*}$ \\
t & $1.25 \pm 0.17$ & $1.62 \pm 0.16^{*}$ & $0.79 \pm 0.20$ & $1.32 \pm 0.21^{*}$ \\
$P$-value & -0.209 & 5.858 & -0.050 & 5.164 \\
\hline${ }^{*} P<0.05$ when compared with before treatment & & 0.961 & $<0.001$ \\
\hline
\end{tabular}

Table 5: Comparison of serum inflammatory cytokines before and after treatment

\begin{tabular}{lcccccc}
\hline \multirow{2}{*}{ Group } & \multicolumn{2}{c}{ CRP $(\mathrm{mg} / \mathrm{mL})$} & \multicolumn{2}{c}{$\mathrm{IL-4}(\mathbf{n g} / \mathbf{m L})$} & \multicolumn{2}{c}{$\mathrm{IL-10}(\mathrm{ng} / \mathrm{mL})$} \\
\cline { 2 - 7 } & $\begin{array}{c}\text { Before } \\
\text { treatment }\end{array}$ & $\begin{array}{c}\text { After } \\
\text { treatment }\end{array}$ & $\begin{array}{c}\text { Before } \\
\text { treatment }\end{array}$ & $\begin{array}{c}\text { After } \\
\text { treatment }\end{array}$ & $\begin{array}{c}\text { Before } \\
\text { treatment }\end{array}$ & $\begin{array}{c}\text { After } \\
\text { treatment }\end{array}$ \\
\cline { 2 - 7 } Study & $6.73 \pm 0.46$ & $3.28 \pm 0.54^{*}$ & $14.93 \pm 0.68$ & $6.83 \pm 0.86^{*}$ & $19.00 \pm 0.57$ & $28.60 \pm 3.35^{*}$ \\
Control & $6.78 \pm 0.44$ & $4.02 \pm 0.57^{*}$ & $15.00 \pm 0.63$ & $8.44 \pm 0.87^{*}$ & $19.01 \pm 0.55$ & $23.77 \pm 2.70^{*}$ \\
$t$ & -0.367 & -5.120 & -0.448 & -7.199 & -0.068 & 6.142 \\
$P$-value & 0.715 & 0.000 & 0.656 & 0.000 & 0.946 & 0.000 \\
\hline
\end{tabular}

${ }^{\star} P<0.05$ when compared with before treatment

\section{Serum inflammatory cytokine levels}

Serum levels of CRP and IL-4 were significantly reduced, while serum level of serum IL-10 was markedly increased in both groups after treatment, when compared with corresponding values before treatment. Serum levels of CRP and IL-4 in the study group were decreased sharply, while serum IL-10 level was markedly increased $(p<0.05)$. These results are shown in Table 5.

\section{Quality of life}

There was no significant difference in the score in quality of life scale between the two groups before treatment. However, after treatment, the total score in Chinese PedSQL scale in both groups were markedly higher than those before treatment, with all study group scores markedly higher than those of control group $(p<0.05$; Table 6).

Table 6: Comparison of quality life before and after treatment

\begin{tabular}{lcc}
\hline \multirow{2}{*}{ Group } & \multicolumn{2}{c}{ Quality of life score } \\
\cline { 2 - 3 } Study & Before treatment & After treatment \\
\cline { 2 - 3 } Control & $74.73 \pm 6.61$ & $86.73 \pm 6.98^{*}$ \\
$\mathrm{t}$ & 1.388 & $77.26 \pm 6.81^{*}$ \\
$P$-value & 0.170 & 5.315 \\
\hline${ }^{*} P<0.05$ when compared with before treatment
\end{tabular}

\section{Adverse reactions}

There was 1 case of mild gastrointestinal reaction, and 1 case of headache in the study group, accounting for $6.67 \%$ incidence of adverse reactions. In the control group, there were 2 cases of mild gastrointestinal reactions, and 1 case of headache, resulting in $10.00 \%$ incidence of adverse reactions. There was no significant difference in the incidence of adverse reactions between the two groups $(x 2=0.218, p$ $=0.064)$. These results are presented in Figure 1.

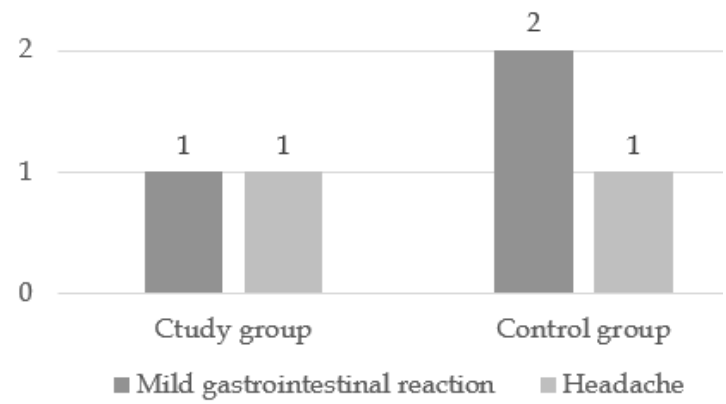

Figure 1: Comparison of adverse reactions between the two groups

\section{DISCUSSION}

The number of children with bronchial asthma in China increases year by year. Relevant

Trop J Pharm Res, September 2021; 20(9): 2008 
epidemiological survey has shown that about $30 \%$ of bronchial asthma patients in China are children under 12 years of age [9]. Asthma has become one of the respiratory diseases that impair children's physical and mental health and quality of life [10]. The disease is due to airway inflammation. Eosinophils, lymphocytes, mast cells and other inflammatory cells infest the airway mucosa and release a large number of inflammatory cell mediators such as leukotrienes, histamine, IL-6, and TNF- $\alpha$, leading to hyperresponsiveness, reversible airflow restriction and airway remodeling [11].

It has been found that the pathogenesis of bronchial asthma is associated with inflammatory response, airway hyperresponsiveness, immune regulation, bacterial infection, as well as environmental and genetic factors [12]. Thus, it is difficult to achieve effective treatment of the disease on account of its complex pathogenesis. Indeed, there is no effective radical cure for bronchial asthma in Western medicine. Glucocorticoids, $\beta$-receptor agonists and leukotriene modulators are most-commonly used, but they all have limitations to some extent [13]. Inhalation glucocorticoids are commonly used drugs in clinical practice, and they act directly on the airway, thereby effectively alleviating the clinical symptoms of bronchial asthma. They are essential drugs in the treatment of bronchial asthma in children [14].

Montelukast is a novel LTRA that specifically binds to leukotriene receptor of the airway, thereby blocking leukotriene-induced inflammation and hyperresponsiveness. It also maintains Th1/Th2 ratio, blocks the synthesis of inflammatory factors such as IL- 6 and TFN- $\alpha$, and regulates immune inflammation, thereby effectively protecting lung function [15].

Montelukast is a non-hormone anti-inflammatory drug which suppresses activation of lymphocytes, eosinophils, monocytes and macrophages; reduces the release of peroxides and oxygen free radicals from these inflammatory cells, and exerts anti-inflammatory and antioxidant effects [16]. The drug is safe and suitable for asthma treatment in children and the elderly, and it is distinctively efficacious in alleviating clinical symptoms, while improving prognosis of asthma in children.

Studies have shown that bronchial asthma is also associated with immune dysfunction, repeated infection, and deficiency of vitamins $A$ and D. Vitamin A level and dietary intake of children with bronchial asthma are lower than those of healthy children; this is also true in comparison between severe bronchial asthma patients and those with mild asthma [18]. There is negative correlation between the severity of bronchial asthma and serum vitamin A levels. Vitamin $A$ regulates immunity, maintains the integrity of airway mucosal epithelium, promotes normal development of airway smooth muscle, reduces airway hyperresponsiveness, and prevents airway remodeling. Thus, vitamin A deficiency may induce or aggravate bronchial asthma. Studies in recent years have shown that vitamin A deficiency lowers the body's resistance to infection. In addition, vitamin $A$ is required for activation of $B$ lymphocytes via enhancement of the synthesis of immunoglobulins and production of secretory $\lg A$ in the respiratory tract.

Vitamin A prevents programmed cell death and maintains the viabilities of $T$ and $B$ lymphocytes. Research has found that children with bronchial asthma often have a deficiency of vitamin $D$, and low level of vitamin $D$ is closely related to allergy and indicators of the severity of bronchial asthma (FEV1, FVC, and serum total Ig E and peripheral blood eosinophil count). Other studies have observed that bronchial asthma patients often have low vitamin D levels. Moreover, patients with low levels of vitamin D often have the highest prevalence of bronchial asthma, suggesting that there may be a certain connection between low level of vitamin $D$ and the incidence of bronchial asthma.

The results obtained in the present study showed that the combination therapy produced significant clinical efficacy. Clinical treatment effectiveness in the study group $(90.00 \%)$ was significantly higher than that of the control group (63.33\%), and the time taken for symptom remission was markedly shorter in the study group. Compared with conditions before treatment, levels of FEV1 and FVC in both groups were significantly increased by treatment, and the study group outperformed the control group.

Serum CRP and IL-4 levels in both groups were significantly lowered after treatment, when compared to values before treatment, while serum IL-10 levels were considerably raised after treatment. Moreover, both groups got higher total scores for Chinese Version of PedSQL after treatment. However, after treatment, the study group had higher scores for all indicators than the control group. This is consistent with findings in other studies.

\section{CONCLUSION}

The combination of montelukast and vitamins $A$ and $D$ drops produces good clinical efficacy in 
children with bronchial asthma. It significantly shortens the time lag before relief of clinical symptoms, improves lung function, reduces inflammatory response, controls asthma, and improves the quality of life of patients.

\section{DECLARATIONS}

\section{Conflict of interest}

No conflict of interest is associated with this work.

\section{Contribution of authors}

We declare that this work was done by the authors named in this article and all liabilities pertaining to claims relating to the content of this article will be borne by the authors.

\section{Open Access}

This is an Open Access article that uses a funding model which does not charge readers or their institutions for access and distributed under the terms of the Creative Commons Attribution License (http://creativecommons.org/licenses/by/ 4.0) and the Budapest Open Access Initiative (http://www.budapestopenaccessinitiative.org/rea d), which permit unrestricted use, distribution, and reproduction in any medium, provided the original work is properly credited.

\section{REFERENCES}

1. Parr CL, Magnus MC, Karlstad $\varnothing$, Holvik K, Lund-Blix NA, Haugen M, Page CM, Nafstad P, Ueland PM, et al. Vitamin $A$ and $D$ intake in pregnancy, infant supplementation, and asthma development: the Norwegian Mother and Child Cohort. Am J Clin Nutr 2018; 107(5): 789-798.

2. Litonjua AA, Carey VJ, Laranjo N, Stubbs BJ, Mirzakhani $H$, O'Connor GT, Sandel M, Beigelman A, Bacharier LB, Zeiger RS, et al. Six-Year Follow-up of a Trial of Antenatal Vitamin $D$ for Asthma Reduction. N Engl J Med 2020; 382(6): 525-533.

3. Curtis EM, Moon RJ, Harvey NC, Cooper C. Maternal vitamin $D$ supplementation during pregnancy. $\mathrm{Br}$ Med Bull 2018; 126(1): 57-77.

4. Larqué E, Morales E, Leis R, Blanco-Carnero JE. Maternal and Foetal Health Implications of Vitamin $D$ Status during Pregnancy. Ann Nutr Metab 2018; 72(3): 179-192.

5. Hutchinson K, Kerley $C P$, Faul J, Greally $P$, Coghlan $D$, Louw $M$, Elnazir $B$, Rochev $Y$. Vitamin $D$ receptor variants and uncontrolled asthma. Eur Ann Allergy Clin Immunol 2018; 50(3): 108-116.
6. Mirzakhani $H$, Litonjua AA, McElrath TF, O'Connor G, Lee-Parritz $A$, Iverson $R$, Macones $G$, Strunk RC, Bacharier LB, Zeiger $R$, et al. Early pregnancy vitamin $D$ status and risk of preeclampsia. J Clin Invest 2016; 126(12): 4702-4715.

7. Department of Health, Education, and Welfare; National Commission for the Protection of Human Subjects of Biomedical and Behavioral Research. The Belmont Report. Ethical principles and guidelines for the protection of human subjects of research. J Am Coll Dent 2014; 81(3): 4-13.

8. Otelea MR, Rascu A. Vitamin D Intake and Obesity in Occupational Asthma Patients and the Need for Supplementation. Endocr Metab Immune Disord Drug Targets 2018; 18(6): 565-572.

9. Ramos-Martínez E, López-Vancell MR, Fernández de Córdova-Aguirre JC, Rojas-Serrano J, Chavarría A, Velasco-Medina A, Velázquez-Sámano G. Reduction of respiratory infections in asthma patients supplemented with vitamin $D$ is related to increased serum IL-10 and IFNY levels and cathelicidin expression. Cytokine 2018; 108: 239-246.

10. Jensen ME, Ducharme FM, Alos N, Mailhot G, Mâsse B, White $J H$, Sadatsafavi M, Khamessan A, Tse SM, Alizadehfar $R$, et al. Vitamin $D$ in the prevention of exacerbations of asthma in preschoolers (DIVA): protocol for a multicentre randomised placebo-controlled triple-blind trial. BMJ Open 2019; 9(12): e033075.

11. Brumpton BM, Langhammer A, Henriksen $A H$, Romundstad PR, Chen Y, Camargo CA Jr, Mai XM. Serum 25-hydroxyvitamin $D$, vitamin $D$ supplement and asthma control: The HUNT study. Respir Med 2018; 136: $65-70$.

12. Mirzakhani H, Carey VJ, Zeiger R, Bacharier LB, O'Connor GT, Schatz MX, Laranjo $N$, Weiss ST, Litonjua $A A$. Impact of parental asthma, prenatal maternal asthma control, and vitamin $D$ status on risk of asthma and recurrent wheeze in 3-year-old children. Clin Exp Allergy 2019; 49(4): 419-429.

13. Hornsby E, Pfeffer PE, Laranjo N, Cruikshank W, Tuzova M, Litonjua AA, Weiss ST, Carey VJ, O'Connor G, Hawrylowicz C. Vitamin $D$ supplementation during pregnancy: Effect on the neonatal immune system in a randomized controlled trial. J Allergy Clin Immunol 2018; 141(1): 269-278.e1.

14. Hennessy Á, Hourihane JO, Malvisi L, Irvine AD, Kenny LC, Murray DM, Kiely ME. Antenatal vitamin D exposure and childhood eczema, food allergy, asthma and allergic rhinitis at 2 and 5 years of age in the atopic diseasespecific Cork BASELINE Birth Cohort Study. Allergy 2018; 73(11): 2182-2191.

15. Tachimoto $H$, Mezawa $H$, Segawa $T$, Akiyama $N$, Ida $H$, Urashima M. Improved control of childhood asthma with low-dose, short-term vitamin $D$ supplementation: a randomized, double-blind, placebo-controlled trial. Allergy 2016; 71(7): 1001-9.

16. El Kinany K, Garcia-Larsen V, Khalis M, Deoula MMS, Benslimane A, Ibrahim A, Benjelloun MC, El Rhazi K.

Trop J Pharm Res, September 2021; 20(9): 2010 
Adaptation and validation of a food frequency questionnaire (FFQ) to assess dietary intake in Moroccan adults. Nutr J 2018; 17(1): 61.

17. Yieh L, McEvoy CT, Hoffman SW, Caughey AB, MacDonald KD, Dukhovny D. Cost effectiveness of vitamin $c$ supplementation for pregnant smokers to improve offspring lung function at birth and reduce childhood wheeze/asthma. J Perinatol 2018; 38(7): 820827.

18. Vollbracht $C$, Raithel $M$, Krick B, Kraft $K$, Hagel AF. Intravenous vitamin $C$ in the treatment of allergies: an interim subgroup analysis of a long-term observational study. J Int Med Res 2018; 46(9): 3640-3655.
19. Ducharme FM, Jensen M, Mailhot G, Alos N, White J, Rousseau E, Tse SM, Khamessan A, Vinet B. Impact of two oral doses of $100,000 \mathrm{IU}$ of vitamin D3 in preschoolers with viral-induced asthma: a pilot randomised controlled trial. Trials 2019; 20(1): 138.

20. Lee-Sarwar K, Kelly RS, Lasky-Su J, Kachroo P, Zeiger RS, O'Connor GT, Sandel MT, Bacharier LB, Beigelman $A$, Laranjo N, et al. Dietary and Plasma Polyunsaturated Fatty Acids Are Inversely Associated with Asthma and Atopy in Early Childhood. J Allergy Clin Immunol Pract 2019; 7(2): 529-538.e8. 